\title{
Effect of tidal dynamics on a planktonic community in a coastal lagoon of Baja California, Mexico
}

\author{
Luis Alberto Morales-Zamorano ${ }^{1}$, Ramón Cajal-Medrano ${ }^{1}$, \\ Elizabeth Orellana-Cepeda ${ }^{1}$, Luis C. Jiménez-Pérez ${ }^{2}$
}

\author{
${ }^{1}$ Facultad de Ciencias Marinas, Universidad Autónoma de Baja California, PO Box 453, Ensenada, Baja California, México \\ ${ }^{2}$ Estación de Investigación Oceanográfica de Ensenada, B.C. Secretaria de Marina, Vicente Guerrero 133, Altos. Fracc. Bahia. \\ CP. 22880, México
}

\begin{abstract}
Fifty-two water samples were collected from the surface at the entrance of a coastal lagoon for evaluation of microheterotrophic processes. The study was carried out during a period of neap and spring tides over 14 consecutive days. Bacteria, microphytoplankton and zooplankton direct counts were made, along with fractionated respiratory activity. Nutrient, C/N ratio, total organic carbon, particulate organic nitrogen, carbon, seston, dissolved oxygen, particulate silica and chlorophyll a determinations were also made. Phytoplankton biomass was low $\left(9.5 \mu \mathrm{g} \mathrm{Cl} \mathrm{Cl}^{-1}\right)$ and was exceeded by bacterial biomass $\left(89.4 \mu \mathrm{g} \mathrm{Cl} l^{-1}\right)$ at both spring and neap tides. Bacterial abundance was independent of tidal height and increased with intense water movement at spring tides. Autotrophic production was limited by light penetration and nutrient availability. Most of the respiratory activity in the water column $(>50 \%)$ occurred in the $\leq 0.8 \mu \mathrm{m}$ size fraction. Bacterial standing stocks sustained carbon production in the water column. Significant negative correlation between bacteria and nanoplankton suggests a trophic structure dependent on dissolved organic carbon inputs from marsh flora, followed by a trophic chain composed of bacteria, nanoplankton, microzooplankton and Acartia sp. It is suggested that food chains stemming from dissolved organic carbon instead of phytoplankton may play a major role in the system since tidal dynamics enhanced bacterial standing stocks during spring and neap tides.
\end{abstract}

\section{INTRODUCTION}

Microheterotrophic organisms, particularly bacteria, play a role not only in mineralization processes but also in organic-matter cycling in marine food chains (Pomeroy 1974, Williams 1981, Azam et al. 1983, Small et al. 1989). Much of this evidence reveals that ca $50 \%$ of the organic matter production in the open ocean can pass through bacteria directly. In the pelagic ocean, phytoplankton production is the major source of organic carbon. However this is not always the case in coastal environments where macrophytes and other carbon sources are present, and energy flow occurs predominantly through the decomposer pathway (Newell 1984).

There is some evidence showing the existence of less conventional food webs starting with dissolved organic carbon, followed by bacterial assimilation, protozoan ingestion and the metazoan food web (Gast 1985, Albright et al. 1987, Roman et al. 1988). These processes may be energetically as important as those based strictly on primary production (Wright 1984, Riemann \& Søndergaard 1986, Mann 1988). Ecologically the dissolved organic carbon (DOC) could be more important than particulate organic carbon (POC), so it becomes necessary to understand in detail the relationship between DOC and planktonic communities in coastal ecosystems (Mann 1988).

For one estuary, Painchaud \& Therriault (1989) have shown that bacterial biomass may exceed that of phytoplankton and that phytoplankton itself was only a minor carbon source. They also observed that physical factors, such as wind and tidal mixing, can reduce phytoplankton production, thus making bacteria a relatively more important component in the structure and function of the system.

Energy fluxes in coastal ecosystems are highly variable depending on whether the dominant pathways are autotrophic or heterotrophic (Wainright 1987). Resuspended nutrients may take a heterotrophic route 
through the planktonic food web, and resuspension in turn will depend on the dynamics of the area and sedimentary characteristics (Wainright 1987).

Resuspension of sediments represents important inputs of both POC and DOC to the water column but its role has been studied in the past mainly as a source of POC for consumers in coastal environments (Woodwell et al. 1977. Turner 1978, Valiela et al. 1978, Imberger et al. 1983, Nixon \& Pilson 1983, Knox 1988). Those studies were concerned with the fate of POC but it now appears that the DOC released in the early stages of decomposition may be ecologically more significant (Mann 1988). There is also some evidence showing that in coastal waters there is a link between phytoplankton and heterotrophic bacteria suggesting that phytoplankton production may also be a major substrate for bacterioplankton (Ferguson \& Palumbo 1979, Fuhrman et al. 1980, Ducklow 1982).

The role of DOC and POC in the pelagic coastal ecosystems is not clearly understood; for a better understanding it is necessary to consider the processes which influence its variability.

Biological variability in coastal ecosystems is governed mainly by tidal height and tidal amplitude which in turn affect light penetration, nutrient concentration, temperature, salinity and pH (Nixon \& Pilson 1983). Biological variability occurs at different time scales (diel, tidal, seasonal cycles), and it is further complicated by spatial variability (Ducklow 1984).

In some coastal lagoons, like those from the west coast of Northern Baja California, plankton production may depend on upwelling events in the nearby area. Consequently high productivity occurs only sporadically (Millán-Nuñez et al. 1981, Abrajan-Villaseñor \& Alvarez-Borrego 1987). In this area, events of high primary productivity in the water column may take place mainly during summer (Muñóz-Anderson 1989). In contrast, the effect of tidal dynamics in the area will be present more frequently as well as the organic carbon inputs of non-planktonjc sources. Thus, it is of interest to investigate if bacterial production may effectively support the trophic structure in these ecosystems during non-upwelling periods. It is also relevant to consider the physical and chemical mechanisms that may control the fluxes of energy in the food web during these events.

To understand how tidal dynamics control the planktonic community we evaluated the variability of total organic carbon (TOC), POC, C/N ratios, seston, nutrients, oxygen, particulate silicon, chlorophyll a, respiratory activity, as well as bacteria, microphytoplankton and microzooplankton abundances for a nonupwelling period of $14 \mathrm{~d}$ at one station on the coastal lagoon Estero Punta Banda on the west coast of Northern Baja California, México

\section{MATERIALS AND METHODS}

The sampling site was located $\mathrm{ca} 1.5 \mathrm{~km}$ from the entrance to the lagoon (Fig. 1). Samples were taken from surface water exclusively at times of maximum low and high tides. Sampling time fluctuated between 3.5 and $12 \mathrm{~h}$ (Fig. 2). Within the 14 sampling days (September 11 to 24,1987 ) one period of neap and spring tides was covered. Water temperature and turbidity were recorded at sampling times.

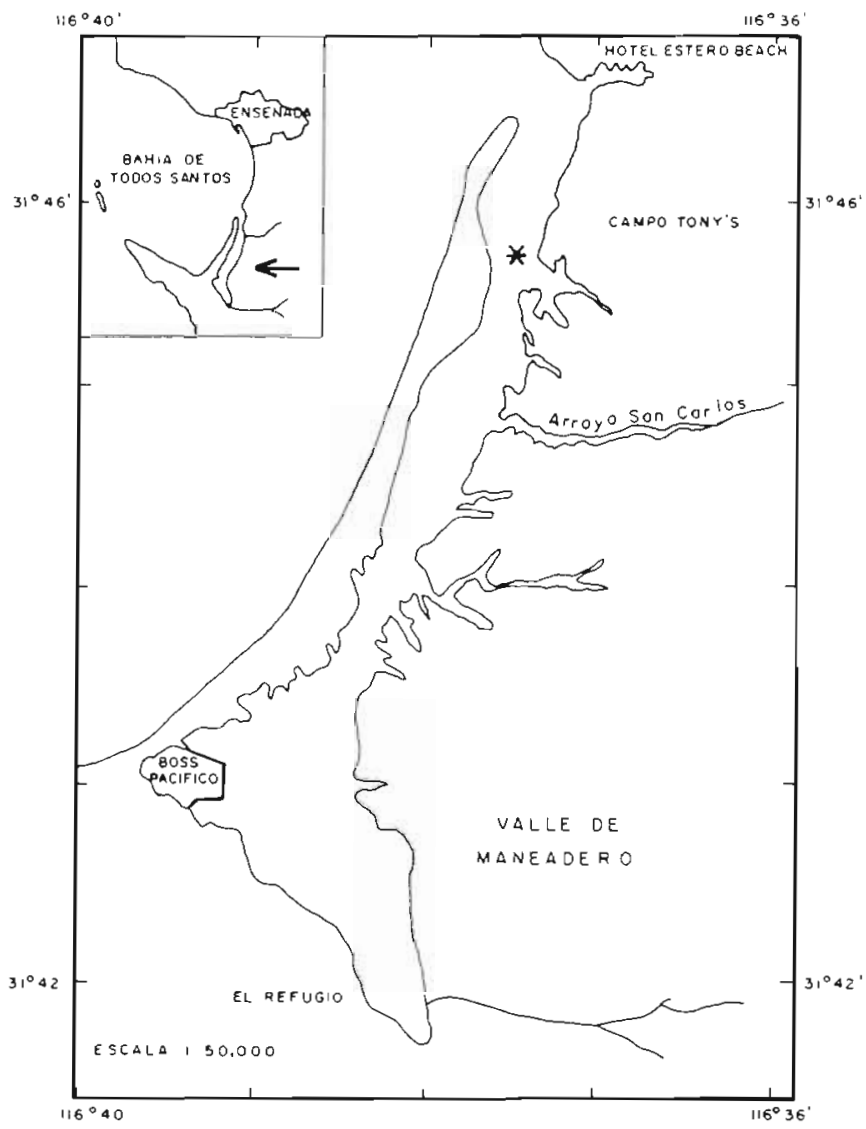

Fig. 1 Study area showing sampling point (star)

Filtering of water for nutrients, seston, chlorophyll $a_{1}$ POC and PON was carred out on land immediately after sample collections and the filters were preserved frozen until analysis.

Analysis for nutrients and chlorophyll a were done spectrophotometrically following Strickland \& Parsons (1972). Particulate biogenic silica (PBS) was determined in $100 \mathrm{ml}$ samples according to Paasche (1980). Samples were hydrolyzed with a dilute solution of sodium hydroxide at $75^{\circ} \mathrm{C}$ for $2 \mathrm{~h}$, and $5 \mathrm{ml}$ of the hydrolyzate was taken for silicic acid determination according to Strickland \& Parsons (1972).

Samples for seston, POC and particulate organic nitrogen (PON) were filtered through previously ashed 
Whatman GF/F filters. Analyses of PON and POC were performed in a CHN analyzer (HP-185B) according to Sharp (1974)

Total organic carbon (TOC) analysis was done with a Beckman 915-B carbon analyzer. Carbonates were removed by acidification with $\mathrm{HCl}$ and bubling of the sample with nitrogen gas. Five replicates of $200 \mu \mathrm{l}$ sample volume were injected and mean values of replicates were determined.

Microphytoplankton and microzooplankton $(20$ to $200 \mathrm{um}$ ) samples were preserved with $3 \mathrm{ml}$ of neutral lugol solution in $300 \mathrm{ml}$ of sample. Occurrence and abundance were determined using the Utermöhl method (Sournia 1978). Microphytoplankton were counted using $25 \times$ (objective) and $12.5 \times$ (eyepiece) covering the whole surface of the $50 \mathrm{ml}$ settling chambers. Total nanoplankton ( 2 to $20 \mu \mathrm{m}$ ) was estimated using diametric transects according to Utermöhl employing $40 \times$ (objective) and $12.5 \times$ (eyepiece). This was used as a minimum estimate of this size fraction since this technique underestimates nanoplankton counts (Davis \& Sieburth 1982).

Bacterial abundance was examined using direct counts with epifluorescence microscopy and acridine orange stains (Hobbie et al. 1977). Exactly $10 \mathrm{ml}$ samples were preserved with $0.5 \mathrm{ml}$ concentrated formaldehyde and were counted within 2 wk. Biomass calculations from phytoplankton and bacterial abundances were obtained using conversion factors, $30 \mu \mathrm{g} \mathrm{C}$ $(\mu \mathrm{g} \mathrm{chl} \mathrm{a})^{-1}$, and $19.8 \mu \mathrm{g} \mathrm{C}$ (bacterial cell) ${ }^{-1}$ (Parsons et al. 1984, Lee \& Fuhrman 1987, respectively).

Mesozooplankton samples were taken with a $300 \mu \mathrm{m}$ mesh net using vertical hauls exclusively. Counts and identification were done according to Jimenez-Pérez et al. (1988)

Plankton size fractions were prepared by passing water samples first through a $180 \mu \mathrm{m}$ plankton net and then through nuclepore filters of $0.8,3$ and 5 um pore sizes. A reverse filtration procedure based on Holm Hansen et al. (1970) was used (Morales-Zamorano 1989). The concentrate was discarded and the water used. Plankton size fractions were in situ incubated in dark BOD bottles over a period of ca $6 \mathrm{~h}$. A high precision Winkler method (Bryan et al. 1976, CajalMedrano et al. 1987) was used for oxygen analyses.

Variance analysis with one way layout was used to test the significance of variables at low and high tide, and spring and neap tides. In order to confirm increase or decrease in the variables during our sampling period, statistical inference on the slope of the regression line was used. Correlation analysis was done using Spearman's correlation coefficients, and results are given with standard errors at the $95 \%$ confidence level. Polynomial regression analyses were used to compare the tendencies of the variables during high and low tides for the whole sampling period.

\section{RESULTS}

Multiple Spearman's coefficient correlation analysis reveals tidal behaviour for seston, oxygen, phosphate and nitrite (Table 1). Seston was correlated significantly with nutrients showing higher values at spring tides with a mean of $46.02 \pm 1.3 \mathrm{mg} \mathrm{l}^{-1}$ (Fig. 3a)
Fig. 2. Tidal height series and sampling time

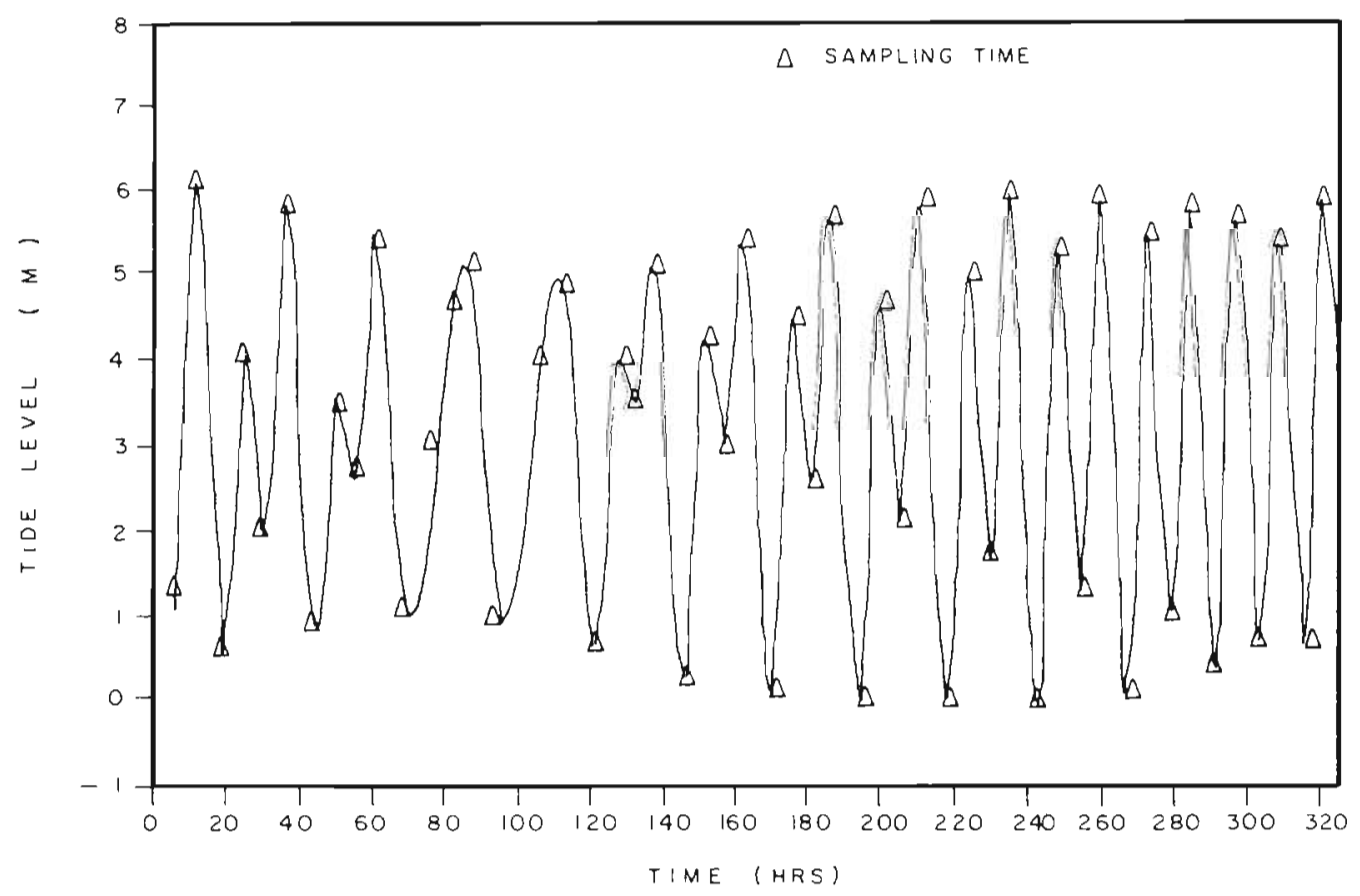


Significantly higher values were also obtained during spring tides for particulate biogenic silicon $(\overline{\mathrm{x}}=4.3 \pm$ $0.76 \mu \mathrm{M})$, nitrate $(\overline{\mathrm{x}}=0.18 \mu \mathrm{M})$, and silicates $(\overline{\mathrm{x}}=3.73$ \pm 0.358 uM) (Fig. 3b to d). During high and low tides we found significant differences in phosphates, nitrites, seston, and oxygen. Higher values were recorded at low tides for phosphates, nitrites and seston (Figs. 3a \& $4 \mathrm{a}, \mathrm{b})$. Higher oxygen values were generally found at high tides (Fig. 4c), and minimum values at low tides suggesting consumption of oxygen by biological and

Table 1 Spearman's correlation coefficient. Underlined numbers: significance at $95 \%$

\begin{tabular}{|c|c|c|c|c|c|c|c|c|c|c|c|c|c|}
\hline & $\mathrm{NO}_{3}$ & $\mathrm{NO}_{2}$ & $\mathrm{PO}_{4}$ & $\mathrm{O}_{2}$ & $\mathrm{SiO}_{2}$ & PSi & $\mathrm{POC}$ & PON & $\mathrm{C} / \mathrm{N}$ & $\mathrm{Chl} \mathrm{a}$ & Seston & Temp. & Tide \\
\hline Bact. & 2448 & .2615 & .0634 & -.1407 & .5744 & 3619 & -.3797 & -1976 & -.1017 & -.1254 & .2259 & 1827 & -.1957 \\
\hline $\mathrm{NO}_{3}$ & $\longrightarrow$ & -.1138 & .0922 & .0988 & .3340 & 2678 & .0621 & 1419 & -.1510 & .2014 & .3108 & 1105 & -.0116 \\
\hline $\mathrm{NO}_{2}$ & & $\longrightarrow$ & .6302 & -4255 & 3991 & .0323 & -.2047 & -.0922 & -.2858 & -.2515 & 3464 & .0457 & -.5865 \\
\hline $\mathrm{PO}_{4}$ & & & $\longrightarrow$ & -4019 &.$\overline{2951}$ & -.0458 & .0429 & 1008 & -.2071 & -1095 & 2981 & .0448 & -6218 \\
\hline $\mathrm{O}_{2}$ & & & & $\longrightarrow$ & -.1518 & 1048 & -1760 & -1469 & 1849 & -.0807 & $-\overline{1560}$ & -.1920 & .6375 \\
\hline $\mathrm{SiO}_{2}$ & & & & & $\longrightarrow$ & .5609 & -.2301 & -.0121 & -.1639 & -.2058 & .4664 & .2961 & $-\overline{3224}$ \\
\hline PSi & & & & & & $\longrightarrow$ & -.1391 & .0640 & .0281 & -.1352 & .4333 & 1451 & $\overline{-.0692}$ \\
\hline POC & & & & & & & $\rightarrow$ & 8993 & .2210 & -.0721 & $-\overline{1474}$ & -.0435 & -.0920 \\
\hline PON & & & & & & & & $\longrightarrow$ & -.0614 & .0184 & -.0160 & -1497 & -.1600 \\
\hline $\mathrm{C} / \mathrm{N}$ & & & & & & & & & $\rightarrow$ & -.0755 & -.2280 & .3190 & .3019 \\
\hline Chl a & & & & & & & & & & $\longrightarrow$ & -.2267 & .0902 & .0919 \\
\hline Seston & & & & & & & & & & & $\longrightarrow$ & .1579 & -.4311 \\
\hline Temp. & & & & & & & & & & & & $\longrightarrow$ & -.0575 \\
\hline
\end{tabular}
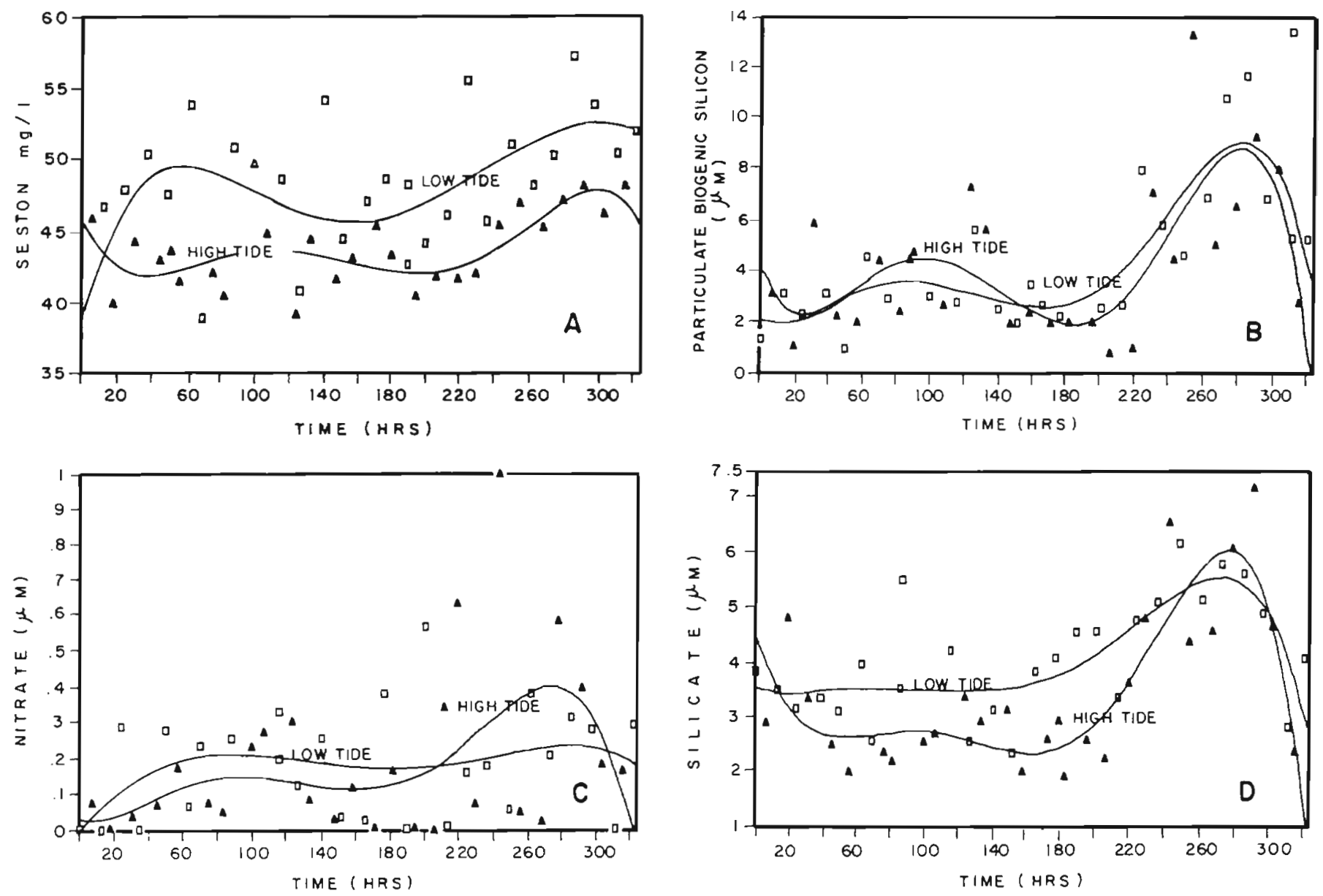

Fig. 3. Tidal variation of seston (a), particulate biogenic silicon (b), nitrate (c), and silicate (d) at low tide and high tide 

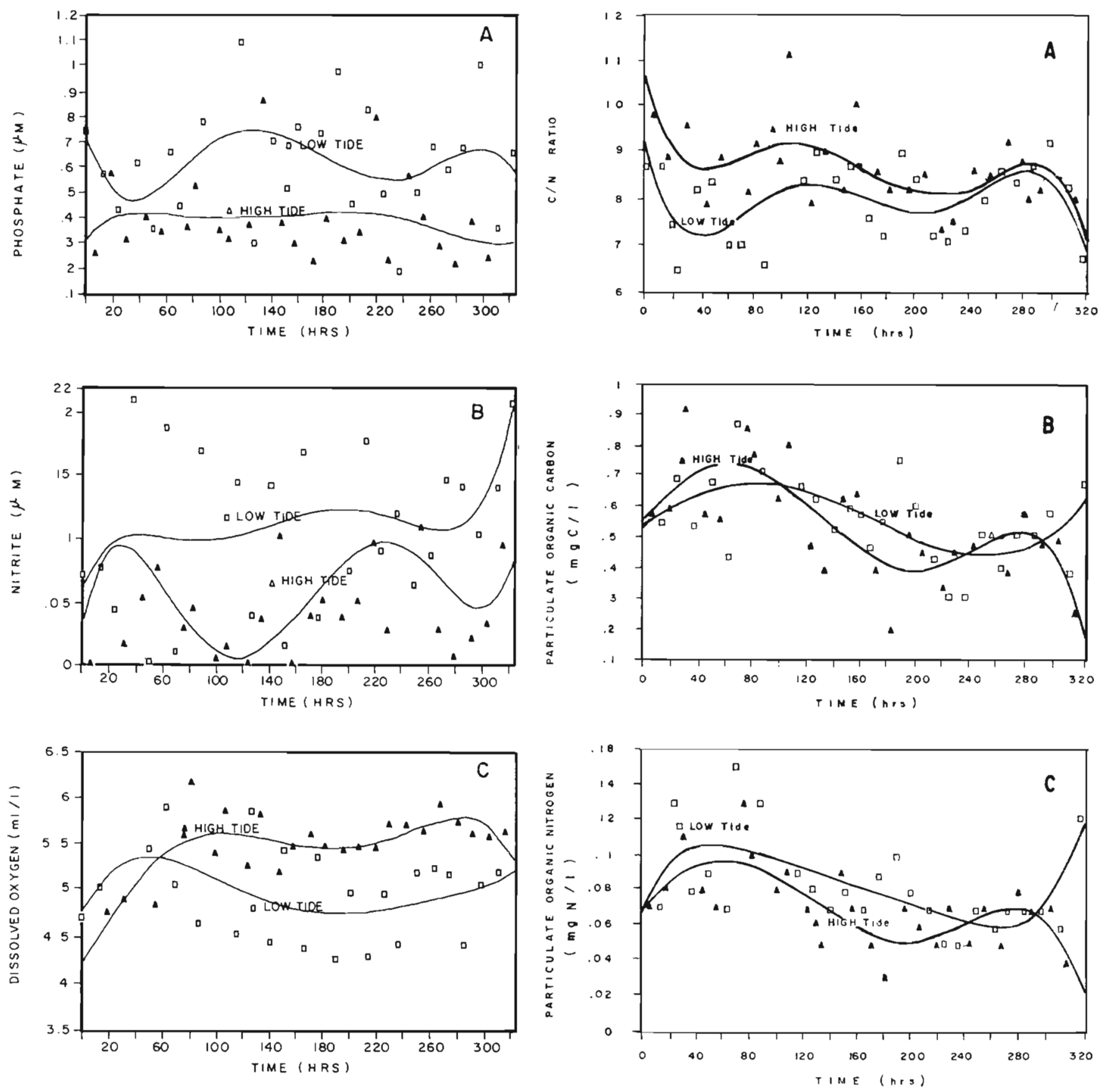

Fig. 4. Tidal variation of phosphate (a), nitrite (b), and dissolved oxygen (c) at low tide and high tide

chemical processes and changes in solubility due to temperature fluctuations.

The variability of the organic material shows a constant $\mathrm{C} / \mathrm{N}$ ratio for the entire sampling period with mean values of $8.5 \pm 0.24$ and no significant differences at low or high tides (Fig. 5a). Particulate organic carbon and nitrogen showed lower concentrations during spring tides with mean values of $0.55 \pm 0.042 \mathrm{mg} \mathrm{C}$ $\mathrm{l}^{-1}$ and $0.08 \pm 0.007 \mathrm{mg} \mathrm{N}^{-1}$ (Fig. 5b, c). Dissolved

Fig. 5. Tidal variation of $\mathrm{C} / \mathrm{N}$ ratio (a), particulate organic carbon (b), and particulate organic nitrogen (c) at low tide and high tide

organic carbon concentrations were calculated from TOC and POC samples and revealed a mean value of $3.2 \pm 0.49 \mathrm{mg} \mathrm{C}^{-1}(\mathrm{n}=19)$ and a mean DOC/POC ratio of 6 for the whole sampling period.

Cumulative respiration documents that the size fraction $<0.8 \mu \mathrm{m}$ respired $56.4 \pm 18.8 \%(\mathrm{n}=5)_{\text {; }}$ size fraction $<3.0 \mu \mathrm{m}, 76.6 \pm 7.7 \% \quad(\mathrm{n}=8)$; size fraction $<5 \mu \mathrm{m}, 96.9 \pm 3.7 \%(\mathrm{n}=13) ;$ the remaining $3.1 \%$ by 
the fractions greater than 5 um but smaller than $180 \mu \mathrm{m}$ (Fig. 6).

Chlorophyll a was not affected by tides; mean values of only $0.3 \pm 0.05 \mathrm{mg} \mathrm{m}^{-3}$ were found. At present, these

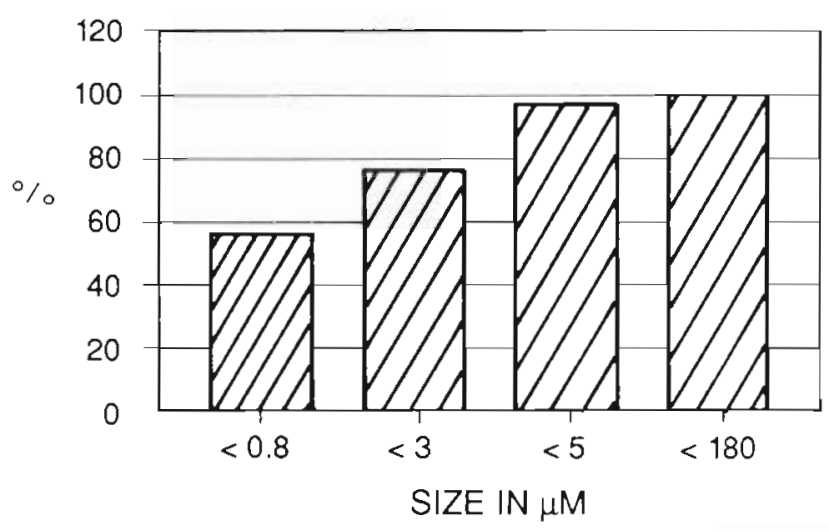

Fig. 6. Cumulative respiration in plankton size fractions values are the lowest reported for the study area (Fig. 7a). High values of pheophytin were also detected only during spring tides $\left(2.9 \pm 0.88 \mathrm{mg} \mathrm{m}^{-3}\right)$. Microphytoplankton ( 2 to $200 \mu \mathrm{m}$ ) abundance was very low (2.2 to 7 cells $\mathrm{ml}^{-1}$ ) but it is within the low end of other reported values (Alvarez-Borrego \& Najera-Munóz 1979). During high tides the highest microphytoplankton abundance was observed $\left(\bar{x}=5.6 \pm 1.4\right.$ cells $\left.\mathrm{ml}^{-1}\right)$, dinoflagellates being the most abundant group. Bacterial abundance was significantly higher at spring tides (overall mean = $4.5 \pm 0.39 \times 10^{6}$ cells $\mathrm{ml}^{-1}$ ) and was not affected by low and high tides (Fig. 7b). The bacterial to microphytoplankton cell ratio ranges from $1.4 \times 10^{5}$ to $4.5 \times 10^{5}$ (Table 2). These ratios are 2 orders of magnitude higher than in other coastal areas (Azam \& Ammerman 1984).

Bacterial abundance and chlorophyll content were converted to carbon using factors of Lee \& Fuhrman (1987) and Parsons et al. (1984). From these estimations it can be seen that bacterial contribution to POC was
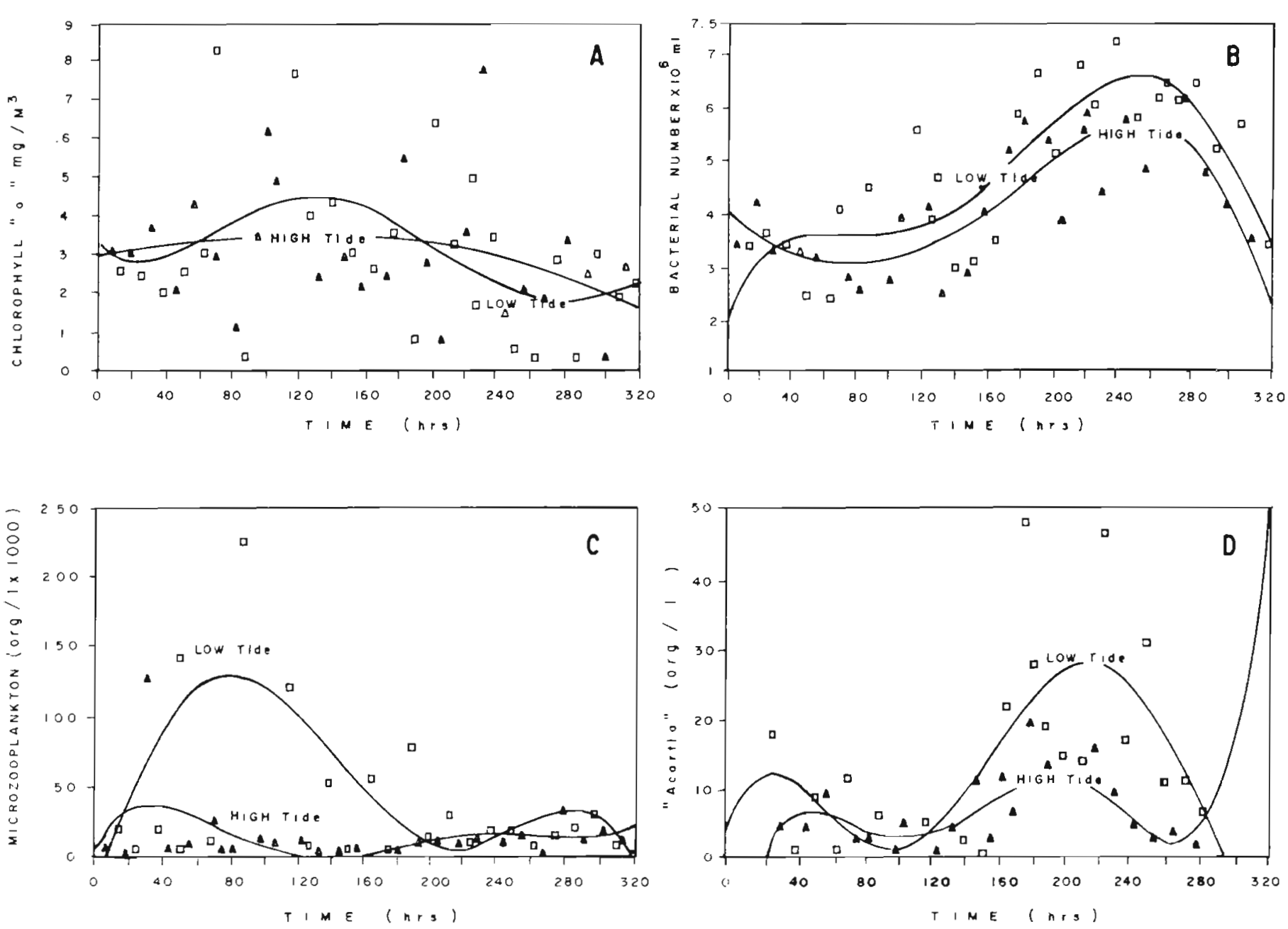

Fig. 7. Tidal variation of chlorophyll a (a), bacterial abundance (b), microzooplankton (c), and Acartıa sp. (d) at low tide and high tide 
Table 2. Relative abundances at Estero de Punta Banda during spring and neap tides

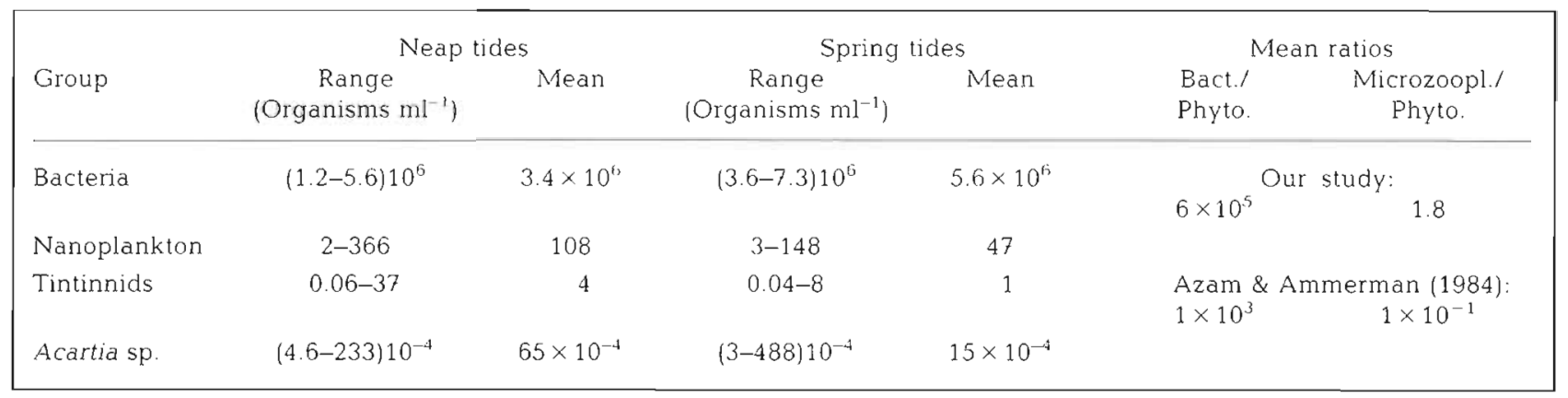

Table 3. Relative contribution of phytoplankton and bacterial biomass to particulate organic carbon

\begin{tabular}{|lcr|}
\hline $\begin{array}{c}\text { Organic } \\
\text { pools }\end{array}$ & $\begin{array}{c}\text { Concentration } \\
\text { ( } \mu \mathrm{C}^{-1} \text { ) }\end{array}$ & Percentage \\
\hline $\begin{array}{l}\text { Phytoplankton } \\
\text { Bacteria }\end{array}$ & 9.5 & 2 \\
Total POC & 89.4 & 16 \\
& 550.0 & 100 \\
\hline
\end{tabular}

roughly 9 times greater than the microphytoplankton contribution (Table 3).

The use of settling chambers in nanoplankton (2 to $20 \mathrm{um})$ counts underestimates the abundance of this size fraction ( 4 to $30 \%$ of the cells as detected by epifluorescence microscopy; Davies \& Sieburth 1982). In spite of that, significant negative correlation was observed between total nanoplankton abundance and bacterial abundance.

The highest microzooplankton densities were present during low tides $\left(\bar{x}=3.0 \pm 1.7 \mathrm{cell} \mathrm{ml}^{-1}\right.$; Fig. $7 \mathrm{c}$ ). Mesozooplankton $(0.3$ to $2 \mathrm{~mm}$ ) mean densities were higher at low tides ( 16 individuals $l^{-1}$ ) than at high tides ( 9 individuals $l^{-1}$ ), and mean values of 13 organisms $l^{-1}$ for both periods. Acartia sp. was conspicuously present throughout the sampling period, representing $90 \%$ of net zooplankton during the whole study (Fig. 7 d, Table 2).

\section{DISCUSSION}

The general pattern of seston, particulate silicon and nitrate indicates greater resuspension of sediments during spring tides. However, short time-scale events like high and low tides also show significant differences in mean values of seston, phosphate and nitrite, suggesting sediment resuspension during these events (Valiela et al. 1978, Knox 1988). Particulate biogenic silicon concentration was relatively high when compared to the Southern California Bight (OrellanaCepeda et al. 1990), probably because our study area is shallower Nutrient concentrations during spring tides were highest for nitrate and silicate. Also higher values were found for nitrite and phosphate during low tides. This suggests that mineralization takes place mainly in sediments and that ammonium, nitrite and phosphates are released as the first by-products to the overlying water. This process influences the water column mainly at low tides. High concentrations of ammonium should be espected since very high (19 to $1970 \mu \mathrm{M}$ ) concentrations in pore waters have been reported for this lagoon (Camacho-lbar \& Alvarez-Borrego 1988). Nitrate is the end product of mineralization and is present in higher concentrations when highest resuspension of sediments takes place at spring tides. Silicates show significant increases in concentration at spring and low tides, indicating also that their concentrations depend on resuspension of sediments. This is also evident from the significant correlation with particulate silicon.

Dissolved oxygen variability is not related to longterm scale events like spring and neap tides. On the contrary, this variable was controlled by physicochemical and biological processes during shorter events like high and low tides.

The concentration of POC was low and similar to that found by Eppley et al. (1977) in the Southern California Bight during low nitrate conditions $(<1 \mu \mathrm{M})$. The POC content decreased during spring tides because of the presence of a larger water volume off the lagoon when the mean water level increased. Because POC was negatively correlated with bacteria it is suggested that higher concentrations of $\mathrm{POC}$ stem from a different source. The most likely sources of POC and DOC in the area are marsh vegetation like Spartina spp. and edaphic algae (Sullivan \& Moncreiff 1990) which could provide the basis for a detritus food chain. In this case the trophic web must be strongly associated with heterotrophic microorganisms. When the contribution of our biomass estimates are compared, in terms of carbon, it can be seen that phytoplankton biomass is much lower $(2 \%)$ than bacterial biomass $(16 \%)$. Moderate 
variability of the low $\mathrm{C} / \mathrm{N}$ ratios and a slight decrease in it during spring tides suggest that bacteria might enrich the nitrogen content of the particles, since their abundance increases at spring tides. Other studies near our study area have revealed wide variations of $\mathrm{C} / \mathrm{N}$ ratios in salt marshes (Lara-Lara et al. 1980). These authors reported $\mathrm{C} / \mathrm{N}$ ratios of 3 to 81 associating the lowest ratios to phytoplankton and bacteria. Hence it is possible that bacterial abundance in the present study masked the high $\mathrm{C} / \mathrm{N}$ ratios of Spartina spp. (20 to 63 ; Harrison \& Mann 1975) and therefore provided highquality biomass for consumers (Wainright 1987).

Bacterial abundance in the water column increased during spring tides due to resuspension of sediments and inputs of labile substrate. Although we did not estimate the amount of labile carbon, DOC mean value was high (3.2 $\mathrm{mg} \mathrm{Cl}^{-1}$ ) suggesting continuous inputs of substrate. Pheophytin values were high during spring tides and cannot be explained from our low chlorophyll a data, hence we presume that macrophyte lecheates are the source of DOC as reported by Imberger et al. (1983) for a southeastem US salt marsh estuary. Bacterial standing stocks increased at spring tides, when the greater water volume off the lagoon reduced the POC content. At this time $\mathrm{C} / \mathrm{N}$ ratios slightly decreased, presumably due to the presence of bacterial cells. Bacterial standing stocks were not correlated with seston but revealed tidal-dependent behaviour So, it is also possible that resuspended sediments promoted bacterioplankton growth (Wainright 1987).

Microphytoplankton abundance was the lowest reported for the study site, however low direct counts are coherent with low chlorophyl a values. It has been suggested that bacteria and algae are the most abundant organisms in coastal surface seawater with a ratio of $10^{3}$ bacterial cells to 1 phytoplankton cell (Azam \& Ammerman 1984). The ratio found in our study $\left(10^{5}: 1\right.$ bacteria to microphytoplankton) shows how variable the coastal lagoon environment can be. Although we do not know how often such a situation may occur, evidence for a similar situation was found by Painchaud \& Therriault (1989) in an estuarine environment.

Production in coastal lagoons derives from photosynthetic producers, macro and microalgae (Knox 1986) or vascular plants (Moran \& Hodson 1989). Microalgae production in this coastal lagoon may be restricted by light penetration. Two days before our study started, primary productivity was measured by the ${ }^{14} \mathrm{C}$ technique showing the lowest reported value for this lagoon $10.8 \mathrm{mg} \mathrm{C} \mathrm{m} \mathrm{C}^{-3} \mathrm{~h}^{-1}$; Munoz-Anderson 1989). Therefore biomass production in the water column would seem to be primarily supported by bacterial production based on DOM from detrital macrophytes. Metabolic activity experiments show that our microheterotrophic community was active, respiring a major portion of the organic carbon into the water column, and that bacteria were quantitatively the main consumers of oxygen. At first approximation our respiration results document that bacteria respired $11.1 \mathrm{mg} \mathrm{C} \mathrm{m}^{-3}$ $\mathrm{h}^{-1}$ on average. Even though carbon conversion efficiency for bacteria is variable (Newell et al. 1981 . Newell 1984, Williams 1984), when a range of 30 to $80 \%$ is assumed we obtain 3.3 to $44 \mathrm{mg} \mathrm{C} \mathrm{m}^{-3} \mathrm{~h}^{-1}$ as an approximation of bacterial production. A mean net community production of $12.2 \mathrm{mg} \mathrm{C} \mathrm{m}^{-3} \mathrm{~h}^{-1}$ was obtained during our study via the oxygen technique (data not shown). This rough estimation indicates that bacterial production may exceed that of microphytoplankton when their abundance is low, or may be comparable to it during periods of high primary productivity in summer. Primary production by phytoplankton insufficient for microheterotrophs has also been found in other ecosystems (Smith et al. 1986, Painchaud \& Therriault 1989) suggesting inputs of organic matter from other sources. However, the accuracy of our estimations is limited, by assumptions regarding bacterial carbon conversion efficiency.

In any event, our respiration data show that the bacterial community in our study was the major metabolic component.

Significant negative correlation between bacteria and nanoplankton, and the dominance of Acartia sp., strongly suggest a heterotrophic food web stemming from organic carbon produced by macrovegetation and transferred by bacteria to other trophic levels (Heinbokel \& Beers 1979, Takx \& Polk 1982, Sieburth 1984, Sherr et al. 1986, Roman et al. 1988). It is likely that microzooplankton constitute the principal diet of Acartia sp. along with detritus associated microorganisms as our high numbers of tintinnids suggest (Robertson 1983. Gifford \& Dagg, 1988).

Pheophytin data suggest that organic carbon from marsh areas caused the increase in bacterial abundance which occurred mainly at spring tides. In contrast, no statistical difference was found in bacterial abundance during low and high tide. Dilution of bacterial abundance with larger volumes of oceanic water at high tides was not observed. This is probably due to rapid bacterial response to organic substrate supply during spring tides.

The data presented here underline the importance of microheterotrophic processes based on DOC from marsh areas as a feasible support of planktonic food web in our study area (Fig. 8) promoted via sediment resuspension by tidal forces. It is of interest to determine the extent of the temporal persistence of this phenomenon.

Primary productivity studies in the area (MillanNúnez et al. 1981, Abrajam-Villaseñor \& Alvarez-Borrego 1987) show that fertilization processes by upwelling may be an important mechanism for production in 


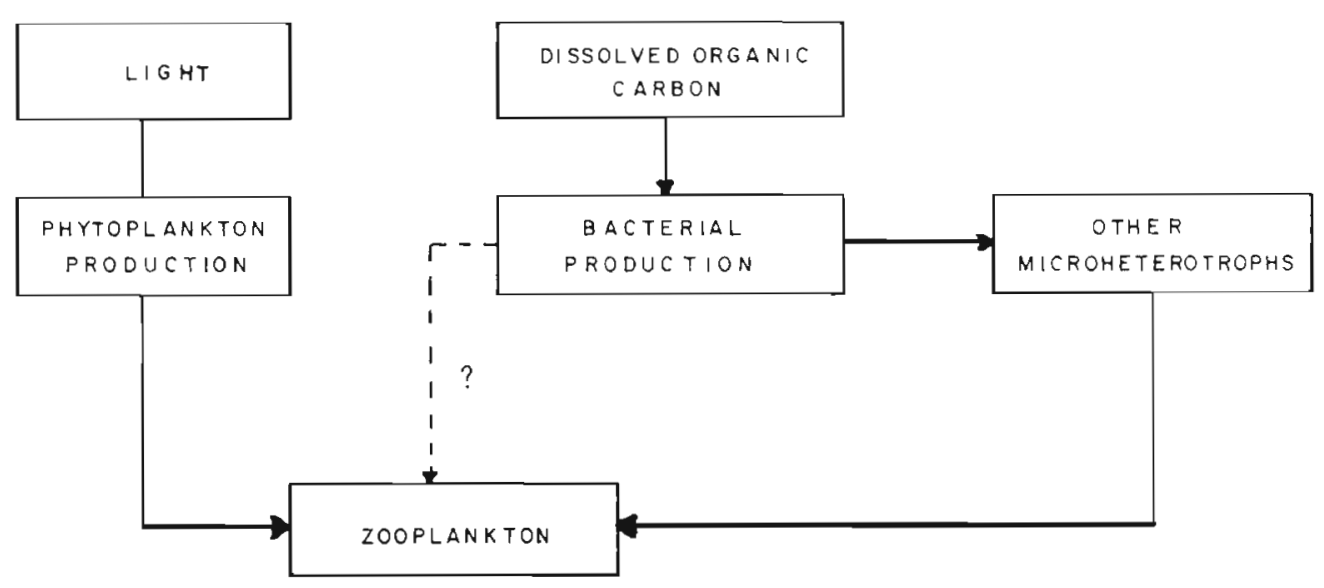

L I G H T

Fig. 8. Conceptual model of trophic interactions at Estero de Punta Banda (after Cajal-Medrano 1990)

the water column. Nonetheless, its occurrence is limited in space and time so the mechanisms of production suggested here may be operating more often than previously thought, and are forced by higher frequency variables like tidal energy.

Acknowledgements. We thank the Secretaría de Educación Pública for supporting this study by grant 87-01-446. We are especially grateful to Dr Farooq Azam for critically reading an early version of this manuscript, and to Dr Richard Eppley for making his facilities available for our particulate organic carbon and nitrogen analyses. E. H. Renger provided assistance and advice with the analysis. This manuscript benefitted greatly from the comments of 2 anonymous reviewers.

\section{LITERATURE CITED}

Abrajan-Villaseñor, I., Alvarez-Borrego, S. (1987). Relación Fotosíntesis-Irradiacia de fracciones de tamaño del fitoplancton de verano de una laguna costera del Noroeste de Baja California. Ciencias Marinas 3: 49-62

Albright, L. J., Sherr, E. B., Sherr, B. F., Fallon, R. D. (1987). Grazing of ciliated protozoa on free and particle-attached bacteria. Mar. Ecol. Prog. Ser. 38: 125-129

Alvarez-Borrego, S., Najera-Múnoz, S. (1979). Series de tiempo del fitoplancton en dos lagunas costeras de Baja California. Ciencias Marinas 6: 75-88

Azam, F., Fenchel, T., Field, J. G., Gray, J. J., Meyer-Reil, L. A., Thingstad, F. (1983). The ecological role of watercolumn microbes in the sea. Mar. Ecol. Prog. Ser. 10: $257-263$

Azam, F., Ammerman, J. W. (1984). Cycling of organic matter by bacterioplankton in pelagic marine ecosystems: microenvironmental considerations. In: Fasham, M. J. R. (ed.) Flows of energy and materials in marine ecosystems. Theory and practice. Plenum Press, New York, p. 345-360

Bryan, J. R., Riley, J. P., Williams, P. J. leB. (1976). A Winkler procedure for making precise measurements of oxygen
Concentrations for productivity and related studies. J. exp mar. Biol. Ecol. 21: 191-197

Camacho-Ibar, V F., Alvarez-Borrego, S. (1988). Nutrient concentrations in pore waters of intertidal sediments in a coastal lagoon: patchiness and temporal variations. The Science of the Tidal Environment 75: 325-339

Cajal-Medrano, R., Mitrani-Abenchuchan, E., CastroDelgado, M. (1987). Sistema fotoelectrónico para titulaciones de oxígeno disuelto con alta precisión y su aplicación en Oceanografía Biológica. (Abstract). Congreso Nacional de Oceanografía, Ensenada B. C., 1987

Cajal-Medrano, R. (1990), Procesos microheterotróficos. In: Rosa-Velez, J., González-Farías, F. (eds.) Temas de oceanografía biológica en México. Universidad Autonoma de Baja California, p. 107-152

Davis, P. G., Sieburth, J. McN. (1982). Differentiation of phototrophic and heterotrophic nannoplankton populations in marine waters by epifluorescence microscopy. Ann. Inst. océanogr., Paris 58: 249-260

Ducklow, H. W. (1982). Chesapeake bay nutrient and plankton dynamics. I. Bacterial biomass and production during spring tidal destratification in the York River, Virginia Estuary. Limnol. Oceanogr. 27: 651-659

Ducklow, H. (1984). Geographical ecology of marine bacteria: physical and biological variability at the mesoscale. In: Klug, M. J., Reddy, C. A. (eds.) Current perspectives in microbial ecology. Am. Soc. for Microbiology, Wash., D.C., p. 22-31

Eppley, R. W., Harrison, W. G., Chisholm, S. W., Stewart, E. (1977). Particulate organic matter in surface waters off Southern California and its relationship to phytoplankton. J. mar. Res. 24: 483-494

Ferguson, R. L., Palumbo, A. V (1979). Distribution of suspended bacteria in the neritic waters south of long Island during stratified conditions. Limnol. Oceanogr. 24: $697-705$

Fuhrman, J. A., Ammerman, J. W., Azam, F. (1980) Bacterioplankton in the coastal euphotic zone: distribution, activity and possible relationships with phytoplankton. Mar Biol. 60: 201-207

Gast, V (1985). Bacteria as a food source for microzooplank- 
ton in the Schlei Fjiord and Baltic Sea with special reference to ciliates. Mar. Ecol. Prog. Ser 22: 107-120

Gifford, D. J., Dagg, M. J. (1988). Feeding of the estuarine copepod Acartia tonsa Dana: carnivory vs. herbivory in natural microplankton assemblages. Bull. mar Sci. 43 $458-468$

Harrison, P. J., Mann. K. H. (1975). Chernical changes during the seasonal cycle of growth and decay in eelgrass (Zoos tera marina) on the Atlantic coast of Canada. J. Fish. Res Bd Can. 32: 615

Heinbokel, J. F., Beers, J. R. (1979). Studies on the functional role of tintinnids in the Southern California Bight. III Grazing impact of natural assemblages. Mar. Biol. 52 23-32

Hobbie, J. E., Daley, R. J., Jasper, S. (1977). Use of nucleopore filters for counting bacteria by fluorescence microscopy. Appl. environ. Microbiol. 33: 1225

Holm-Hansen, O., Packard, T T., Pomeroy, L. R. (1970) Efficiency of reverse flow filter technique for the concentration of particulate matter. Limnol. Oceanogr 15 832-835

Imberger, J., Berman, T., Christian, R. R., Sher, E. B., Whitney, D. E., Pomeroy, L. R., Wiegert, R. G., Wiebe, W. J. (1983) The influence of water motion on the distribution and transport of materials in a salt marsh estuary. Limnol Oceanogr. 28: 201-214

Jiménez-Pérez, L. C., Mancilla-Peraza, M., Martínez-García, G. (1988). Agrupamiento superficial diurno de Calanus pacificus Brodsky (copepoda calanoida) en la Bahía de Todos Santos, Baja California, México. Ciencias Marinas 14: $77-90$

Knox, G. A. (ed.) (1988). Estuarine ecosystems: a system approach. Vol. I. C. R. C. Press, Florida

Lara-Lara, R., Alvarez-Borrego, S., Small, L. F. (1980). Variability and tidal exchange of ecological properties in a coastal lagoon. Estuar coast. mar Sci. 11: 613-637

Lee, S., Fuhrman, J. A. (1987). Relationships between biovolume and biomass of naturally derived marine bacterioplankton. Appl. environ. Microbiol. 53: 1298-1303

Millán-Núñez, E., Ortiz-Cortéz, F. J., Alvarez-Borrego, S. (1981). Variabilidad temporal y espacial de nutrientes y fitoplancton en una laguna costera a finales de verano. Ciencias Marinas 3: 49-62

Mann. K. H. (1988). Production and use of detritus in various freshwater, estuarine and coastal marine ecosystems. Limnol. Oceanogr. 33: 894-909

Morales-Zamorano, L. A. (1989). Papel trófico de microheterótrofos marinos durante un período de marea muertaviva en el Estero de Punta Banda, B. C., México. MSc. thesis, Facultad de Ciencias Marinas, Universidad Autónoma de Baja California

Moran, M. A., Hodson, R. E. (1989). Furmation and bacterial utilization of dissolved organic carbon derived from detrital lignocellulose. Limnol. Oceanogr. 36: 1034-1047

Muñoz-Anderson, M. (1989). Variación anual de la producción fitoplanctónica primaria en el Estero de Punta Banda, Baja California, México. BSc. thesis, Facultad de Ciencias Marinas, Universidad Autónoma de Baja California

Newell, R. C., Lucas, M. I. Linley, E. A. S. (1981). Rate of degradation and efficiency of conversion of phytoplankton debris by marine microorganisms. Mar. Ecol. Prog. Ser. 6 . 123-126

Newell. R. C. (1984). The biological role of detntus in the marine environment. In: Fasham, M. J. R. (ed.) Flows of energy and materials in marine ecosystems. Theory and practice. Plenum Press, New York, p. 317-343

Nixon, S. W., Pilson, M. C. (1983). Nitrogen in estuarine and coastal marine ecosystems. [n: Carpenter, E. J., Capone D. G. (eds.) Nitrogen in the marine environment. Academic Press. New York, p. 565-648

Orellana-Cepeda, E., Renger, E. H., Nelson, J. R., Eppley, R. W (1990). Particulate biogenic silica in the euphotic zone off Southern California. Ciencias Marinas 16: 69-89

Paasche, E. (1980). Silicon Content of five marine plankton diatom species measured with a rapid filter method. Limnol. Oceanogr. 23: 474-480

Painchaud, J., Therriault, J. C. (1989). Relationships between bacteria, phytoplankton and particulate organic carbon in the Upper St. Lawrence Estuary. Mar. Ecol. Prog. Ser 56: 301-311

Parsons, T R., Takahashi, M., Hargrave, B. (eds.) (1984). Biological oceanographic processes, 3rd edn. Pergamon Press, New York

Pomeroy, R. L. (1974). The oceans food web. A changing paradigm. Bioscience 24: 499-504

Rieman, B., Sondergaard, M. (1986). Carbon dynamics in eutrophic temperate lakes. Elsevier, Amsterdam

Robertson, J. R. (1983). Predation by estuarine zooplankton on tintinnid ciliates. Estuar. coast. Shelf Sci. 16: 27-36

Roman, M. R., Ducklow, H. W., Ferguson, J. A., Garside, C., Glibert, P. M., Malone, T C., McManus, G. B. (1988) Production, consumption and nutrient cycling in a laboratory mesocosm. Mar Ecol. Prog. Ser. 42: 39-52

Sharp, J. H. (1974). Improved analysis for particulate organic carbon and nitrogen for seawater. Limnol. Oceanogr. 19 984-989

Sherr, E. B., Sherr, B. F., Fallon, R. D., Newell, S. Y (1986). Small aloricate ciliates as a major component of the marine heterotrophic nannoplankton. Limnol. Oceanogr. 31 $177-183$

Sieburth, J. M. (1984). Protozoan bacterivory in pelagic marine waters. In: Hobbie, J. E., Williams, P. J. LeB (eds.) Heterotrophic activity in the sea. Plenum Press, New York, p. 406-444

Small, L. F., Laundry, M. R., Eppley, R. W., Azam, F., Carlucci, A. F. (1989). Role of plankton in the carbon and nitrogen budgets of Santa Monica Basin California. Mar. Ecol. Prog. Ser 56: 57-74

Smith, H. R., Harrison, W G., Irwin, B., Platt, T (1986). Metabolism and carbon exchange in microphytoplankton of the Grand Banks (Newfoundland). Mar. Ecol. Prog. Ser 34: $171-183$

Sournia, A. (ed) (1978). Phytoplankton Manual. UNESCO

Strickland, J. D. H., Parsons, T R. (eds.) (1972). A practical handbook of seawater analysis, 2nd edn. Bull. Fish. Res. Bd Can. 167: $1-310$

Sullivan, M. J., Moncreiff, C. A. (1990). Edaphic algae are an important component of salt marsh food-webs: evidence from multiple stable isotope analyses. Mar. Ecol. Prog. Ser. 62: $149-159$

Takx, M., Polk, P. (1982). Feeding of Acartia tonsa Dana (Copepoda, Calanoida): predation of nauplii of Canvella perplexa T. A. Scott (copepoda, harpacticoidea), in the sluice - dock of Ostend. Hidrobiology 94: 131-133

Turner, R. E. (1978). Community plankton respiration in a salt marsh estuary and the importance of macrophytic leachates. Limnol. Oceanogr. 23: 442-451

Valiela, I., Teal, J. M., Volkman, S., Shorter, D., Carpenter, E. J. (1978). Nutrient and particulate fluxes in a salt marsh ecosystem: tidal exchanges and inputs by precipitation and groundwater. Limnol. Oceanogr 23: 798

Wainright, S. C. (1987). Stimulation of heterotrophic microplankton production by resuspended marine sediments. Science 238: $1710-1712$ 
Williams, P. J. leB (1981). Incorporation of microheterotrophic processes into the classical paradigm of the planktonic food web. Kieler Meeresforsch. (Sonderh.) 5: 1-28

Williams, P. J. leB (1984). A review of measurements of respiration rates of marine plankton populations. In: Hobbie, J. E., Williams, P. J. leB (eds.) Heterotrophic activity in the sea. Plenum Press, New York, p. 357-389

Woodwell, G. M., Whitney, D. E., Hall, C. A. S., Houghton,

This article was submitted to the editor
R. A. (1977). The Flax Pond ecosystem study: exchanges of carbon in a water between a salt marsh and Long Island Sound. Limnol. Oceanogr 22: 833-838

Wright, R. T (1984). Dynamics of pools of dissolved organic carbon. In: Hobbie, J. E., Williams, P. J. leB (eds.) Heterotrophic activity in the sea. Plenum Press, New York, p. 121-154

Manuscript first received: February 2, 1990

Revised version accepted: September 26, 1991 